OPEN ACCESS

Approved by:

Frontiers in ICT Editorial Office, Frontiers Media SA, Switzerland

*Correspondence:

Sébastien Cajot

sebastien.cajot@alumni.epfl.ch

Specialty section:

This article was submitted to Human-Media Interaction,

a section of the journal

Frontiers in ICT

Received: 18 March 2019 Accepted: 19 March 2019 Published: 09 April 2019

Citation:

Cajot S, Schüler N, Peter M, Koch A and Maréchal F (2019) Corrigendum: Interactive Optimization With Parallel

Coordinates: Exploring

Multidimensional Spaces for Decision

Support. Front. ICT 6:6.

doi: 10.3389/fict.2019.00006

\section{Corrigendum: Interactive Optimization With Parallel Coordinates: Exploring Multidimensional Spaces for Decision Support}

\author{
Sébastien Cajot ${ }^{1 *}$, Nils Schüler ${ }^{1}$, Markus Peter $^{2}$, Andreas Koch $^{2}$ and Francois Maréchal ${ }^{1}$ \\ ${ }^{1}$ IPESE, Ecole Polytechnique Fédérale de Lausanne, Sion, Switzerland, ${ }^{2}$ European Institute for Energy Research, \\ Karlsruhe, Germany
}

Keywords: interactive optimization, parallel coordinates, MILP, MCDA, urban planning, multiobjective optimization, data visualization

\section{A Corrigendum on}

Interactive Optimization With Parallel Coordinates: Exploring Multidimensional Spaces for Decision Support

by Cajot, S., Schüler, N., Peter, M., Koch, A., and Maréchal, F. (2019). Front. ICT 5:32. doi: $10.3389 /$ fict.2018.00032

In the original article, the reference for "Inselberg, 2009" was incorrectly written as "Inselberg, A. (2009). "Parallel Coordinates," in Encyclopedia of Database Systems, eds L. Liu and M. T. Özsu (Dordrecht: Springer), 2018-2024." It should be "Inselberg A. (2009). Parallel Coordinates: Visual Multidimensional Geometry and Its Applications. New York, NY: Springer."

The authors apologize for this error and state that this does not change the scientific conclusions of the article in any way. The original article has been updated.

\footnotetext{
Copyright () 2019 Cajot, Schüler, Peter, Koch and Maréchal. This is an open-access article distributed under the terms of the Creative Commons Attribution License (CC BY). The use, distribution or reproduction in other forums is permitted, provided the original author(s) and the copyright owner(s) are credited and that the original publication in this journal is cited, in accordance with accepted academic practice. No use, distribution or reproduction is permitted which does not comply with these terms.
} 